\title{
THE RESEARCH OF PHYSICAL CONDITION, PHYSICAL ACTIVITY AND NUTRITION OF TEACHER EDUCATION STUDENTS
}

\author{
Renata Kiserauskaitè, Dalia Paškevičienè \\ Vilnius Pedagogical University, Lithuania
}

\begin{abstract}
The goal of the research is to identify and assess parameters of physical development, actual nutrition, energy expenditure and energy requirement of the young adult males. The research was conducted in 20082010 and students $(n=84)$ of biology, physical education and psychology specialties at Vilnius Pedagogical University participated in it. Height and weight measurements were taken by electronic medical scales with the height measuring equipment. We analysed an average energy value of a daily food ration; the intake of carbohydrates, protein, and fat; physical activity and energy requirement by using 7-day nutrition and physical activity diaries filled out by the students participating in the research (20.35 \pm 0.99 years old). The body weight of the majority of the young adult males was normal (69.05 per cent), 26.19 per cent of them had the body weight above the normal range, and the body weight of 4.76 per cent of the students was insufficient. Physical activity ratio of the future teachers is $1.79 \pm 0.382$. An average energy value of nutrition ration corresponds to energy expenditure $(p=0.684)$ but is lower than energy requirement $(p<0.001)$. The ratio of the main nutrients (protein, fat, and carbohydrates) in the nutrition of the young adult males is unbalanced; 27.38 per cent of them consume too much protein, and 1.19 per cent exceeds the recommended daily intake of protein more than twice. According to our data, only 7.14 per cent of the students get enough fat, 36.91 per cent of them consume too much fat, and 55.95 per cent of the respondents get too little fat although close to the norm. Our research demonstrated that there is a deficiency of carbohydrate in a daily ration food of 95.24 per cent of the young adult males, and the carbohydrate content in the nutrition of 34.52 per cent of the young men is more than twice lower than the norm. In comparison with the individual norms of these nutrients (considering the respondent's body
\end{abstract}


weight, age, and physical activity), protein intake of the young adult males is too high $(\mathrm{p}<0.001)$, the received fat content corresponds to the recommended intake $(\mathrm{p}=0.663)$, and there is carbohydrate deficiency in a daily food ration $(\mathrm{p}<0.001)$.

Key words: students, physical condition, physical activity, nutrition.

\section{INTRODUCTION}

There are certain peculiarities of physical condition and the related lifestyle at every stage of human life. Both in Lithuania and in other countries of the world, the conducted thorough and comprehensive researches of physical condition in children and teenagers are especially important for the further human development. However, after the teenage stage a person enters the stage of youth, and that is like a transition to the mature stage of human life. The lifestyle for most young adults changes: they become more self-dependent, have to change the rhythm of daily activities and their physical activity. At this period of life it is especially important to maintain and improve their physical condition, the habits of rational nutrition, as well as work and leisure regime, because all that makes an essential base for good health, physical and mental efficiency, spiritual comfort and self-confidence. A period of university studies is one of the most important personality development stages related to learning when a person is under constant stress, and that requires great willpower and emotional efforts. Unfortunately, students lack time for eating; therefore, their nutrition regime and health get worse. This is proved by a number of researches carried out at higher education institutions both in Lithuania and in other European countries [3, 6, 8, 15, 18]. There are numerous scientific studies in social and biomedical areas aimed at the assessment of social development, professional readiness, health, physical development data of different groups of young adults $[1,2,7,11,13,15,17]$. Despite the fact that the published data quite thoroughly analyse the situation of young adults, each conducted research, however, provides additional information and reflects the specificity of a certain region, some social group or a stage of life which blend into a general context of researches and are important for the development of the society and for the future. 
According to the data of the World Health Organization (WHO), 40 60 per cent of the human health depends on the lifestyle, 30-40 per cent is impacted by the environment, $10-15$ per cent is inherited, and only $8-$ 10 per cent of health depends on health care [19]. At birth, every person acquires a certain health potential which he strengthens throughout his entire life or may also weaken it. A person himself is responsible for his own health and has to take care of it, to strengthen and cherish it. In order to maintain good health and not to deteriorate the quality of life, it is necessary to follow certain principles of holistic lifestyle: rational nutrition, the enhancement of physical and mental powers, physical activity, and the refusal of harmful habits. It is also necessary to select food individually, to use more functional foods. Optimum movement is a precondition to live a full-fledged life at all stages of human life. According to the WHO data, already on the second day after the decrease in physical activity, mental activity reduces up to 50 per cent, the concentration of attention declines, nervous tension increases, etc. [19].

\section{MATERIAL AND METHODS}

The students $(n=84)$ of biology, physical education and psychology took part in the research. Their average age was $20.35 \pm 0.99$ years old. The total sample of the research was divided into two groups: the students whose physical activity ratio was from 1.2 to 1.5 (low and moderate physical activity) belonged to the first group, and the second group consisted of the students whose physical activity ratio was from 2 to 2.7 (high and very high physical activity). Electronic medical scales SECA 704 with the height measuring equipment SECA 220 were used to measure the physical development parameters. To study actual nutrition and physical activity, we used 7-day nutrition and physical activity diaries filled out by each student participating in the research in accordance with the consumed quantity of food and the size of portions as well as the energy expenditure for daily activities. To determine food portions, we used A Photographic Atlas of Food Products and Food Portion Sizes (2007). The quantities of protein, fat, and carbohydrates, as well as the food energy value, were determined referring to food composition tables [5]. Energy expenditure was assessed according to the tables of energy expenditure in different types of activities of The Basics of Sports Medicine. Having analysed a 7-day nutrition ration (the 
composition of food and meals, the nutritional and energy value) and physical activity, an average daily energy value of a nutrition ration (kcal), energy expenditure ( $\mathrm{kcal}$ ), a physical activity ratio, and an individual energy requirement were calculated. A physical activity ratio was determined by the recommendations of the World Health Organization: 1.2 means very low physical activity; 1.3 - low physical activity; 1.5 - moderate physical activity; 2.0 - high physical activity; 2.7 - very high physical activity. The daily energy requirement (DER) was calculated according to the formulae: $\mathrm{DER}=\mathrm{BMR} \times \mathrm{PAR}(\mathrm{BMR}-$ basal metabolic rate; PAR - physical activity ratio), $B M R=65.4+(13.7 \times \mathrm{W})+$ $(5.0 \times \mathrm{H})-(6.8 \times \mathrm{A})(\mathrm{W}-$ body weight, $\mathrm{kg} ; \mathrm{H}-$ height, $\mathrm{cm} ; \mathrm{A}-$ age in years). The statistical analysis was performed using the STATISTICA 6.0 software package. Statistical significance was determined by applying the Student's t-test and the Kruskal-Wallis test criteria of independent samples.

\section{RESULTS}

According to the data of the specialists consistently researching actual nutrition and the lifestyle of the Lithuanian population, the recent changes in the body weight of the Lithuanian population are adverse to their health: the number of people, having insufficient or excess body weight, has been increasing [4, 9]. It is known that physiological functions of the people having insufficient body weight may be impaired, and obese people are at risk to get non-infectious diseases (WHO). The average values of physical development of the students involved in our research: height $-183.26 \pm 7.378 \mathrm{~cm}$, body weight $79.19 \pm 11.402 \mathrm{~kg}, \mathrm{BMI}-23.53 \pm 2.664 \mathrm{~kg} / \mathrm{m}^{2}$ (Table 1). The body mass index (BMI) of a majority (69.05 per cent) of future teachers is within the normal range, while BMI of 26.19 per cent of the students is above the normal range (Figure 1). This is an on-going research $[10,12]$ supplemented with an additional number of respondents, new methodologies, and data interpretations. 


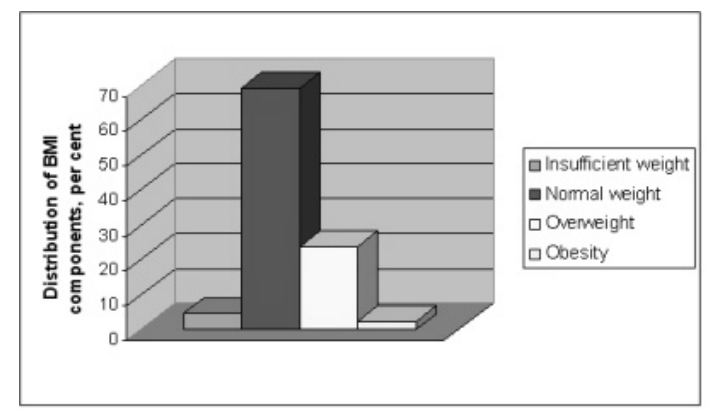

Figure1. Physical development data of the young adult males.

An average energy value of food is $2466.95 \pm 812.753 \mathrm{kcal}$ : fat -912.72 kcal (103.51 g), carbohydrates - $1142.54 \mathrm{kcal}(287.93 \mathrm{~g})$, and protein $411.69 \mathrm{kcal}(101.22 \mathrm{~g})$. The daily average energy expenditure - 2591.69 \pm 671.561 , the average of physical activity ratio $-1.79 \pm 0.382$, according to which the daily energy requirement is $3457.13 \pm 834.319$ kcal (Table 1, Table 2).

Table 1. Physical development, the energy value of the food ration, energy expenditure and energy requirement of the young adult males

\begin{tabular}{|c|c|c|c|c|c|c|c|}
\hline \multirow[b]{2}{*}{$\begin{array}{l}\text { Young adult } \\
\text { males, } n=84\end{array}$} & \multirow[b]{2}{*}{$\begin{array}{l}\text { Height, } \\
\mathrm{cm}\end{array}$} & \multirow[b]{2}{*}{$\begin{array}{c}\text { Weight, } \\
\mathrm{kg}\end{array}$} & \multirow[b]{2}{*}{$\begin{array}{l}B M I, \\
\mathrm{~kg} / \mathrm{m}^{2}\end{array}$} & \multirow{2}{*}{$\begin{array}{c}\text { Food } \\
\text { energy } \\
\text { value, } \\
\text { kcal }\end{array}$} & \multicolumn{2}{|c|}{ Physical activity } & \multirow{2}{*}{$\begin{array}{c}\text { Daily } \\
\text { energy } \\
\text { requirem } \\
\text { ent, } \\
\text { kcal }\end{array}$} \\
\hline & & & & & $\begin{array}{c}\text { Daily energy } \\
\text { expenditure, } \\
\text { kcal }\end{array}$ & Ratio & \\
\hline Average & 183.26 & 79.19 & 23.53 & 2466.95 & 2591.69 & 1.79 & 3457.13 \\
\hline $\begin{array}{l}\text { Standard } \\
\text { deviation }\end{array}$ & 7.38 & 11.40 & 2.66 & 812.75 & 671.56 & 0,38 & 834.32 \\
\hline $\begin{array}{l}\text { Maximum } \\
\text { value }\end{array}$ & 199.00 & 123.00 & 32.35 & 5359.20 & 4366.00 & 2.70 & 6046.38 \\
\hline $\begin{array}{l}\text { Minimum } \\
\text { value }\end{array}$ & 167.00 & 56.00 & 18.21 & 673.70 & 1222.14 & 1.20 & 1867.92 \\
\hline Median & 182.00 & 78.50 & 23.13 & 2360.48 & 2606.00 & 2.00 & 3499.23 \\
\hline
\end{tabular}

One of the principles of healthy lifestyle is rational nutrition and consistent maintenance of the proportion of the nutrients having energy value. According to physiological nutrient and energy norms that ensure physiological needs of the individual, protein must make up 10-15 per 
cent, fat $-28-30$ per cent, and carbohydrates $-55-62$ per cent of the energy value of the daily food ration (Order No. 510 of the Minister of Health of the Republic of Lithuania of 25 November 1999). Referring to the data obtained during our research, the ratio of energetic nutrients in the diet of the students is very diverse (Table 2; Figure 2, 3 and 4). In the daily nutrition of all (100 per cent) the researched young adult males the ratio of the main nutrients (protein, fat, and carbohydrates) is unbalanced.

Table 2. The energy value of the main nutrients in the daily food ration of the young adult males

\begin{tabular}{|l|c|c|c|}
\hline Main nutrients & $\begin{array}{c}\text { Quantity }(g) \\
M \pm S D\end{array}$ & $\begin{array}{c}\text { Energy value (kcal) } \\
M \pm S D\end{array}$ & $\begin{array}{c}\text { Energy value } \\
\text { (proc.) } M \pm S D\end{array}$ \\
\hline Fat & $103.51 \pm 46.880$ & $912.72 \pm 392.435$ & $36.62 \pm 9.994$ \\
\hline Carbohydrates & $287.93 \pm 113.343$ & $1142.54 \pm 450.465$ & $46.20 \pm 9.469$ \\
\hline Protein & $101.22 \pm 37.849$ & $411.69 \pm 157.487$ & $17.18 \pm 6.259$ \\
\hline
\end{tabular}

Protein is important for the different physiological functions of the body; however, as a source of energy it makes up the smallest part, and the body will use protein energy only in case of the shortage of carbohydrates; 27.38 per cent of the young adult males consume too much protein, and 1.19 per cent of them exceed the recommended protein intake more than twice because eggs, meat dishes and leguminous vegetables constitute a significant part in their daily food ration. Fat is the energy substance which is hard to expend; however, fat deficiency can slow down its metabolism in the body. Our research demonstrates that only 7.14 per cent of the students get the sufficient quantity of fat, 36.91 per cent of them consume too much, and 55.95 per cent of the respondents receive too little fat although close to the norm (Figure 3). Carbohydrates are the main and most easily accessible source of energy. Moreover, other components important for physiological processes enter the body together with carbohydrates: minerals, vitamins, fibre, and water. Fibre and water give a sense of satiety, but their energy value is low. This is particularly important for the overweight or obese people. The research showed that 95.24 per cent of the students lack carbohydrates in their daily food ration, and the quantity of carbohydrates consumed by 34.52 per cent of the young adult males is more than twice lower than the norm. Having compared 
the quantities of the main nutrients in the daily food ration with the individual norm of these nutrients (taking into account the respondent's body weight, age and physical activity), we determined that the protein intake is too high $(\mathrm{p}=0.0003)$ (Figure 2.), the fat intake meets the recommended rate $(p=0.663)$ (Figure 3$)$, and there is carbohydrate deficiency in nutrition $(\mathrm{p}=0.000)$ (Figure 4).

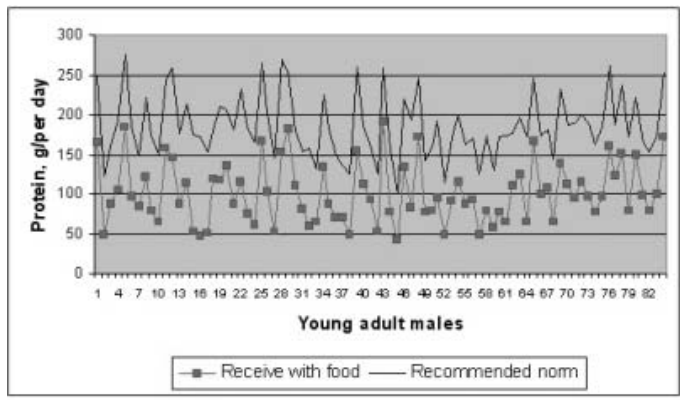

Figure 2. The quantity of protein in the daily food intake of the young adult males compared with the recommended norm, $\mathrm{p}<0.005$.

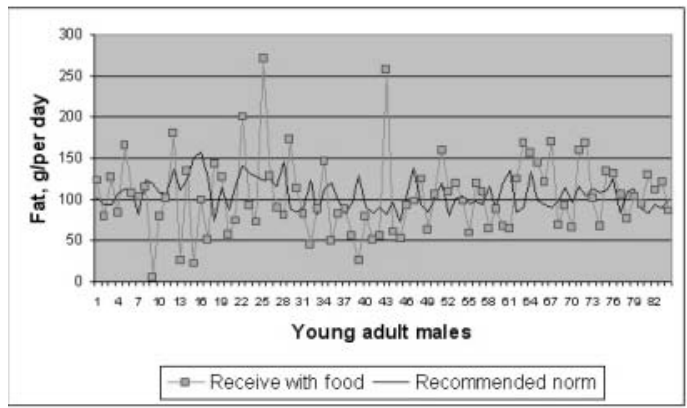

Figure 3. The quantity of fat in the daily food intake of the young adult males compared with the recommended norm, $\mathrm{p}>0.05$. 


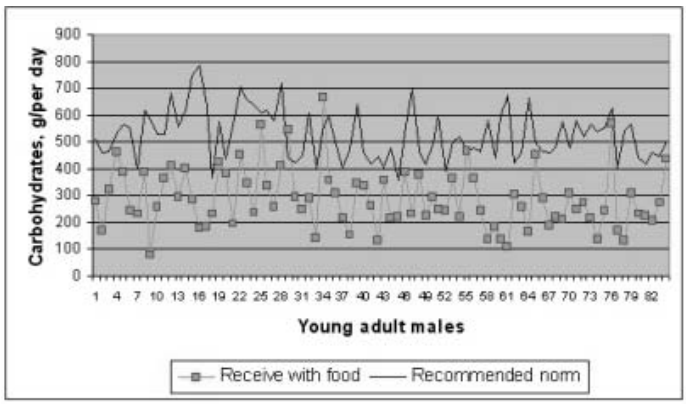

Figure 4. The quantity of carbohydrates in the daily food intake of the young adult males compared with the recommended norm, $\mathrm{p}<0.005$.

The assessment of physical activity data demonstrates that a majority of future teachers (58.33 per cent) are of high and very high physical activity (2-2.7), while 15.48 per cent (1.2 to 1.5 ) of them are of low and very low physical activity (Figure 5 ).

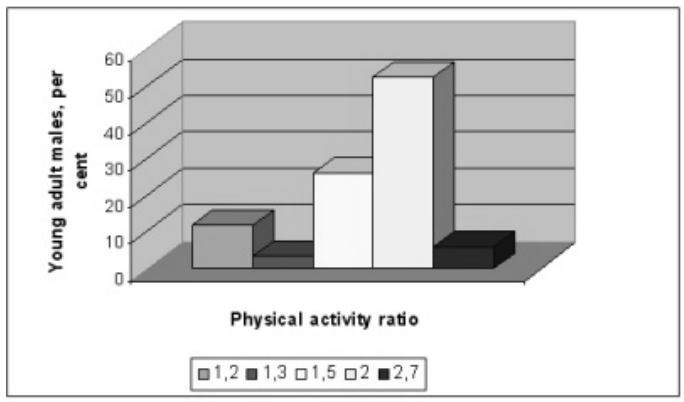

Figure 5. Distribution of the physical activity ratio of the young adult males.

In the average daily food ration of both trial groups (according to the students' physical activity), the quantities of protein, fat, and carbohydrates (kcal) were similar ( $\mathrm{p}>0.05)$. The activities of physically active students are basically related to sports, and their nutrition is dominated by poultry and fish products, various kinds of porridge, chocolate, nuts, raisins. The students whose physical activity is low and moderate eat more junk food: pizzas, kebabs, kybyns, chips, sandwiches, etc. The sources of fat are basically the same: oil, butter and 
other food products containing fat: sour cream, mayonnaise, fatty meat; however, fat reserves of the young adult men who actively go in for sports are supplemented with eggs, milk, and chocolate. In the food ration of the students whose physical activity is high and very high the quantity of carbohydrates (per cent) is closer to the WHO recommended norms; however, there is no essential difference between the two trial groups ( $\mathrm{p}>0.05)$ (Figure 6).

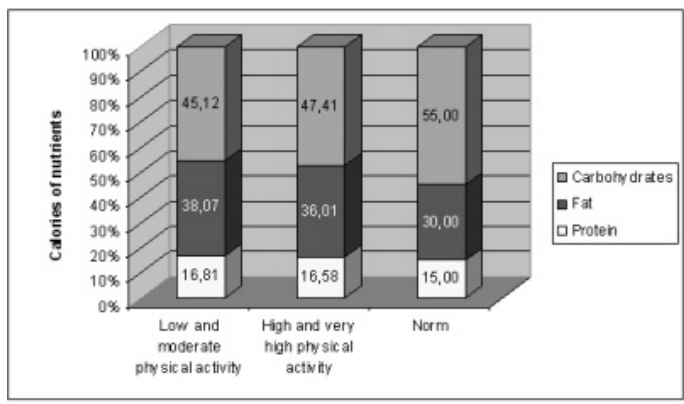

Figure 6. A part of energy value (per cent) in a daily food ration of the young adult males of different physical activity and the WHO recommended norm.

The data of the research demonstrate that according to the results of physical development and physical activity, the quantity of energy in the daily food ration of the young adult males is insufficient. The students whose physical activity is high and very high receive less energy with food than they should get in accordance with their physical activity and basal energy metabolism $(p=0.000)$ (Figure 8). Energy value of the food consumed by the students of low and moderate physical activity is also lower than the energy requirement $(p=0.000)$ (Figure 9). The energy expenditure compared with the energy requirement is also lower in both groups $(\mathrm{p}<0.001)$ (Figure 8,9$)$. 
Boxplot by Group

Data of the young adult males whose physical activity is high and very high

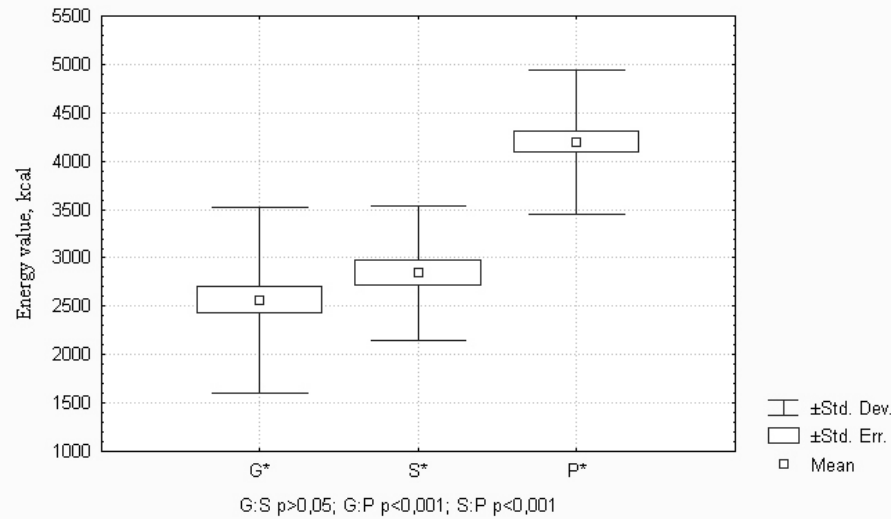

Figure 7. The comparison of the energy value of food, energy expenditure and energy requirement of the young adult males whose physical activity is high and very high $\left(\mathrm{G}^{*}\right.$ - energy value of food (received energy); $\mathrm{S}^{*}-$ energy expenditure; $\mathrm{P}^{*}$ - energy requirement).

Boxplot by Group

Data of the young adult males whose physical activity is low and very low

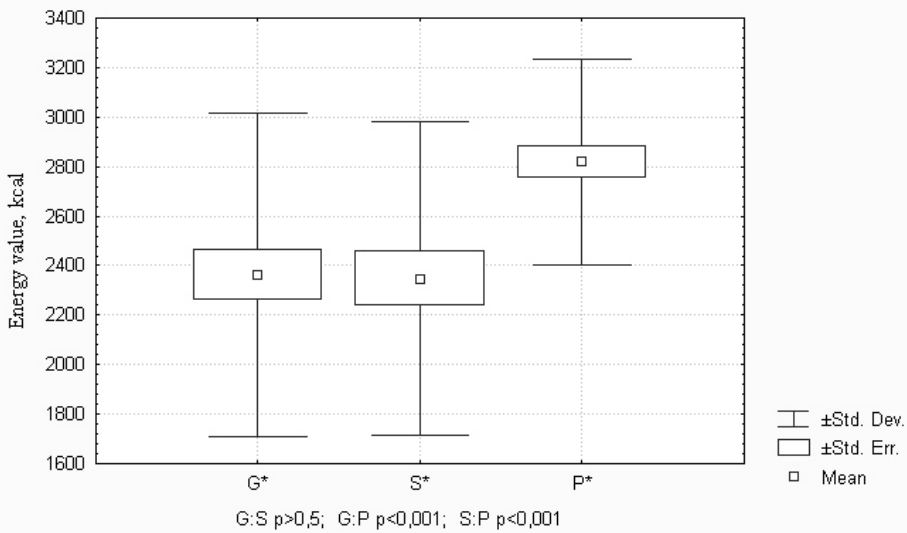

Figure 8. The comparison of the energy value of food, energy expenditure and energy requirement of the young adult males whose physical activity is moderate and low $\left(\mathrm{G}^{*}\right.$ - energy value of food (received energy); $\mathrm{S}^{*}$ energy expenditure; $\mathrm{P}^{*}$ - energy requirement). 


\section{DISCUSSION}

According to the data obtained in 1952-1962, the average height of the male students (21-30 years old) of Kaunas higher schools was 173.82 $\mathrm{cm}$, and the average body weight was $68.2 \mathrm{~kg}$ [16]. Therefore, after four decades young adult males are taller by $9.44 \mathrm{~cm}$ and heavier by $10.99 \mathrm{~kg}$. Compared with the body mass index of the first-year students of the Western Region higher schools of the United States of America [17], the data of our research demonstrate that 0.76 per cent of the young adult males have insufficient body weight, while a number of overweight students is bigger by 9.81 , and a number of obese young men is smaller by 3.62 per cent. The energy value of food ration of the U.S. students, whose body mass index is less than 25 [17], was by $192.3 \mathrm{kcal}$ higher compared with our respondents; meanwhile, the energy value of the food consumed by those, whose BMI is above the normal range ( $\geq 25)$, was less by $23.84 \mathrm{kcal}$. The daily energy value of the food ration of the students participating in the research is lower by $139.05 \mathrm{kcal}$ in comparison with the value of the food ration of the Lithuanian men but by $188.59 \mathrm{kcal}$ higher compared with the Estonian men and lower by $116.05 \mathrm{kcal}$ compared with the Latvian men [1]. However, compared with the data of high-performance sportsmen [13], our researched students get even $2019.05 \mathrm{kcal}$ less energy with food.

In the average daily food ration of future teachers fat made up $36.6 \pm$ 10 per cent (Table 2), and according to the data of J. A. Abaravicius (2008), fat made up by 8.8 per cent more in the nutrition of the Lithuanian men (25-64 years old) and by 6.1 per cent more in the food of the Latvian men but only by 0.1 per cent less in the food ration of the Estonian men. Future teachers receive relatively little carbohydrates $46.2 \pm 9.5$ per cent while in the food ration of the Lithuanian men carbohydrates constitute even a smaller part i. e. $39.4 \pm 12.3$ per cent. The protein intake of the Lithuanian men corresponded to physiological nutrition standards, and according to our obtained results, the protein norm is exceeded by 2.18 per cent, but 58.33 per cent of the young adult males take active part in sports. Having compared the distribution of the quantity of main nutrients in the food ration of the young adult males with the data of the athletes, active in more endurance requiring kinds of sports [13], our researched students use less of these nutrients: the difference in protein intake makes $46.82 \mathrm{~g}$, in fat $-88.55 \mathrm{~g}$, and in carbohydrates $-164.69 \mathrm{~g}$. The quantitative ratio of protein, fat and 
carbohydrates in the actual food ration of sportsmen is $1: 1,3: 3,1$ [13], and this ratio in our researched group is $1: 1,03: 2,74$. Both studies show carbohydrate deficiency in the nutrition of the young adult males.

The development of nutrition researches in Lithuania reveals essential changes in the consumption of energy nutrients: in 1933, in the nutrition of Lithuanian farmers protein made 11 per cent of the daily food intake, fat -17 per cent, and carbohydrates -70 per cent. The researches of lifestyle and actual nutritional of adult Lithuanians conducted by the National Nutrition Centre in 1997-1998 show that the nutrition of adult Lithuanians has notably changed: the fat intake has significantly increased while the carbohydrate intake has decreased, a lot of cholesterol which unfavourably affects health has appeared in food, nutrition has become irrational and unbalanced [14]. Our researches as well as the researches carried out by other authors only confirm that $[1$, $13,15]$.

According to the data of J. A. Abaravicius (2008), the energy expenditure of the people in most Central and Eastern European countries, including Lithuania, has been constantly decreasing. The research data demonstrate that low physical activity is typical of the respondents of the Baltic countries, but 16.6 per cent of the Lithuanian men are active in sports more frequently. The physical activity of the researched young adult males is high (physical activity ratio is $1.79 \pm$ $0.38)$.

\section{CONCLUSIONS}

1. The body weight of the majority of the young adult males is normal (69.05 per cent), 4.76 per cent of them have insufficient body weight, and the body weight of 26.19 per cent of the young adult males is above the normal range.

2. The ratio of the main nutrients, i.e. protein, fat, and carbohydrates, in the food ration of the young adult males is unbalanced.

3. The young adult males consume too much protein $(\mathrm{p}<0.001)$, the fat intake meets the recommended norm $(\mathrm{p}=0.663)$; however, there is carbohydrate deficiency in nutrition $(\mathrm{p}<0.001)$.

4. The energy value of the daily ration corresponds to the energy expenditure $(p=0.684)$ but it is lower than the daily energy requirement $(\mathrm{p}<0.001)$. 


\section{REFERENCES}

1. Abaravičius J. A. (2008) Suaugusių Lietuvos gyventojų faktinès mitybos ir gyvensenos veiksnių tyrimas ir vertinimas. Habilitacijos procedūrai teikiamų mokslo darbų apžvalga. Vilnius: Vilniaus universiteto leidykla. $52 \mathrm{p}$.

2. Ángeles-Llerenas, A., Carbajal-Sánchez, N., Allen, B., Zamora-Muñoz, S., Lazcano-Ponce, E. (2005) Gender, Body Mass Index and Sociodemographic Variables Associated with Knowledge about Type 2 Diabetes Mellitus among 13293 Mexican Students. In: Acta Diabetologica, 42(1), 36-45.

3. Baak M. A. (1999) Physical Activity and Energy Balance. In: Public Health Nutrition. 2(3a), 335-339.

4. Barzda A., Brimas G., Bartkevičiūtė R., Abaravičius A., Olechnovič M. (2004) Suaugusių Lietuvos gyventojų kūno masė: vertinimas ir pokyčių tendencijos. In: Medicinos teorija ir praktika, 3(39), 182-184.

5. Barzda A., Olechnovič M., Bartkevičiūtè R., Abaravičius A., Stukas R., Viseckienè V. (2005) Patiekalų sudètis, maistinè ir energinè vertè. Vilnius: UAB "Valdo leidykla". $228 \mathrm{p}$.

6. Duda B. (2006) Nutrition and Body Mass Assessment of Extramural Students from the Medical Academy and the Academy of Physical Education and Sport in Gdansk. In: Acta medina Lituanica. V.13, No 1, 34-37.

7. Godoy R., Wilkie D. S., Reyes-Garcia V., Leonard W. R., Huanca T., Mcdade T., Vadez V., Tanner S. (2006) Human Body-Mass Index (weight in $\mathrm{kg} /$ stature in $\mathrm{m}^{2}$ ) as a Useful Proxy to Assess the Relation between Income and Wildlife Consumption in Poor Rural Societies. In: Biodiversity and Conservation, 15, 4495-4506.

8. Harro M., Oja L., Tekkel M., Aru J., Villa I., Liiv K. Jürimäe T., Prättälä R., Pudule I., Klumbiene J. (2006) Monitoring Physical Activity in Baltic Countries: the FINBALT Study, HBSC and other Surveys in Young People. In: J Public Health, 14, 103-109.

9. Kadziauskienė K., Bartkevičiūtė R., Olechnovič M. (1999) Suaugusių Lietuvos žmoniu gyvensenos ir faktiškos mitybos tyrimas. Vilnius: Respublikinis mitybos centras. $92 \mathrm{p}$.

10. Kiserauskaitè, R.; Paškevičienè, D.; Semaška V. (2010) Būsimų pedagogų mitybos, fizinès būklès ir fizinio aktyvumo tyrimai. In: Sporto mokslas. Nr. 4, 62, p. 33-38.

11. Mikolajczyk R. T., Ansari W. E., Maxwell A. E. (2009) Food Consumption Frequency and Perceived Stress and Depressive Symptoms 
among Students in Three European Countries. In: Nutrition Journal, 8, 31.

12. Paškevičienè, D.; Kiserauskaite, R. (2009) The Research of Physical Development, Physical Activity, Energy Value of Food and Energy Expenditure of Future Teacher Education Students. In: The $5^{\text {th }}$ Biannual Conference "Baltic Morphology 2009", 22-23.

13. Pečiukonienè M., Stukas R., Kemerytè-Riaubienè E. (2009). Sportininkų mitybos, fizinio išsivystymo ir įmičio būklès tyrimas bei jų tarpusavio sąsajų vertinimas. In: Sporto mokslas, 1(55), 42-48.

14. Petereit R. Mityba [interaktyvus]. (2009) [Žiūrèta 2010 m. lapkritis 7 d.]. Prieiga per internetą:

$<$ http://www.dietologe.lt/viewpage.php?page_id=3>

15. Stukas R., Dobrovolskij V. (2009). Visuomenès sveikatos studentu mitybos ypatumai. In: Sveikatos mokslai, 1(61), 2147-2153.

16. Vegertas V., Z. (1963) Kauno aukštujų mokyklų studentų fizinio išsivystymo dinamika ir kai kurios fiziologinès savybès [Rankraštis]: /1952-1962 m.m. duomenys/: disertacija medicinos mokslų kandidato laipsniui igyti. $293 \mathrm{p}$.

17. Wengreen J. H., Moncur C. (2009). Change in Diet, Physical Activity, and Body Weight among Young-Adults during the Transition from High School to College. In: Nutrition Journal, 8(32), doi:10. 1186/1475-2891-8-32.

18. Westerterp K. R. (2008) Physical Activity as Determinant of Daily Energy Expenditure. In: Physiology \& Behaviour, 93, 1039-1043.

19. World Health Organization (2003) Diet, Nutrition and Prevention of Chronic Diseases. Report of a Joint WHO/FAO Expert Consultation: WHO Technical Report Series 916. Geneva.

\section{Address for correspondence:}

Dalia Paškevičienè

Vilnius Pedagogical University

Studentu str. 39, LT-08106 Vilnius, Lithuania

E-mail: Dalia.Paskeviciene@vpu.lt 